\title{
DZIALALNOŚĆ DUSZPASTERSKA OO. BERNARDYNÓW Z KRAKOWA W LATACH 1918-1939
}

Upadek państwowości polskiej, jaki miał miejsce na przełomie XVIII i XIX wieku, okazał się brzemienny w skutkach dla Polaków nie tylko z punktu widzenia sytuacji politycznej czy społeczno-gospodarczej, ale też kościelnej. Władze zaborcze zmierzały, bowiem do poddania Kościoła katolickiego swej kontroli zarówno w zakresie administracji jak i jego działalności zewnętrznej. Jednym z przejawów tej ostatniej była, podobnie jak dziś praca społeczna będąca zawsze domeną zakonów. Te zaś borykały się wówczas $\mathrm{z}$ wieloma trudnościami, a najbardziej z zagrożeniem ich bytu, w postaci częstych kasat klasztorów oraz prób regulowania przez władze zaborcze napływu nowicjuszy, co odbijało się niekorzystnie na dalszym rozwoju zakonu. Sytuacje tę dodatkowo skomplikował wybuch wojny w roku 1914. Toteż nic dziwnego, że po jej zakończeniu i odzyskaniu przez Polskę niepodległości, starano się nadrobić poniesione straty, tym bardziej, że sprzyjało temu ustawodawstwo państwowe. Nadało, bowiem Kościołowi katolickiemu w Polsce bardzo uprzywilejowane stanowisko, zapewniające mu samodzielność w zarządzaniu swymi sprawami. Gwarantowały to postanowienia konstytucji marcowej z 1921 r., potwierdzone później przez konkordat zawarty ze Stolicą Apostolską w 1925 r. oraz konstytucja kwietniowa $\mathrm{z}$ roku $1935^{1}$.

Ustawy te stworzyły dobre warunki także dla rozwoju bernardyńskiej prowincji ${ }^{2}$, której patronką obwołano Matkę Bożą Niepokalanie Poczęta.

${ }^{1}$ K. G ru d z i ń s k i OFM, Bernardyni w latach 1772-1970, [w:] Zakony św. Franciszka w Polsce w latach 1772-1970, pod red. J. R. Bara. OFM Conv., cz. 3, Warszawa 1978, s. 37; J. Kło c zowski, L. Mülle row a, J. Skarbek, Zarys dziejów Kościoła katolickiego w Polsce, Kraków 1986, s. 307-308.

${ }^{2}$ Bernardyni to polska nazwa obserwantów nadana im ze względu na wezwanie pierwszych kościołów fundowanych dla Zakonu Braci Mniejszych na ziemiach polskich - w Krakowie, Warszawie, Poznaniu i Lwowie, których patronem był św. Bernardyn ze Sieny. Należą oni do rodziny Zakonu Braci Mniejszych (Ordo Fratrum Minorum) założonego przez św. Franciszka z Asyżu z początkiem XIII wieku. Po śmierci Zakonodawcy doszło w zakonie do sporów na tle przepisów Reguły dotyczących przestrzegania ewangelicznego ubóstwa. W zwiazku z tym wyłoniły się ich stronnictwa różniące się sposobem interpretacji. Jedno z nich stanowili obserwanci, ugrupowanie umiarkowane, które zyskało poparcie Stolicy Apostolskiej. Uznani za główny trzon Zakonu Braci Mniejszych zostali wyodrębnieni w roku 1517, jako osobny zakon, 
Okres zaborów i wojny przysporzył polskim bernardynom wiele trosk. Po odzyskaniu niepodległości musieli oni sprostać wielu problemom. Do nich należała rewindykacja skasowanych przez Austriaków klasztorów oraz ich odremontowanie i uposażenie, jako że często pozbawione one były dawnego majątku. Niełatwym zadaniem okazało się również ich obsadzenie. Na przeszkodzie stały tu straty osobowe poniesione przez prowincję. Jedną $z$ ich przyczyn była polityka zaborców zmierzająca do ograniczenia napływu nowicjuszy. Straty ponoszono także $w$ wyniku działan wojennych. Wielu braci powołanych pod broń straciło życie lub poniosło znaczny uszczerbek na zdrowiu. Wielu też znalazło się w niewoli, w której pozostawali jeszcze długo po wojnie. Zwiększeniu liczebności zakonu przeszkadzał też brak Kolegium Serafickiego wymaganego od kandydatów do klasztoru ${ }^{3}$.

$\mathrm{Z}$ potrzebą renowacji borykały się też klasztory, które uniknęły kasaty, ale $\mathrm{z}$ braku środków finansowych popadły w ruinę. Do nich należał również klasztor na Stradomiu w Krakowie ${ }^{4}$. Okres niewoli narodowej przyczynił się nie tylko do utraty przez niego znaczenia w zakonnej prowincji na wskutek przydzielenia go do Prowincji Galicyjskiej (1852) na siedzibę, której wyznaczono Lwów, ale także do znacznego jego zubożenia. Powodem takiego stanu rzeczy był brak bieżących dochodów i jednoczesne konieczne renowacje pochłaniające ogromne sumy, a także utrata części legatów znajdujących się w innych zaborach. Tę wyjątkowo złą dla klasztoru sytuację pogarszał jeszcze fakt, że musiał on mieścić w swych murach uciążliwych lokatorów. Od roku 1838 mieściła się tu, bowiem siedziba policji oraz areszt więźniów politycznych. Za czasów austriackich lokowano tutaj koszary artylerii, a po ich usunięciu aż do roku 1908 urządzono w tak zwanym starym refektarzu stajnie dla koni wojskowych ${ }^{5}$. Wybuch I wojny światowej przyniósł kolejne obciążenia.

na mocy bulli papieża Leona X „Ite et vos in vineam meam” oraz „Omnipotens Deus” - H. E. W y c z a w s k i OFM, Krótka historia Zakonu Braci Mniejszych, [w:] Klasztory bernardyńskie w Polsce w jej granicach historycznych, pod red. H. E. Wyczawskiego. Kalwaria Zebrzydowska 1985, s. 581, 598, 619; H. Ragan, Nazwa oo. Bernardynów w Polsce, Lwów 1928, s. 14.

${ }^{3}$ J. K e d z i o r OFM, Bernardyni w Odrodzonej Polsce, [w:] Kalendarz Dzwonka Trzeciego Zakonu, Kraków 1939, s. 61, 64; K. G r u d z i ń s k i OFM, Bernardyni w latach 1772 $-1970 \ldots .$, s. 37; Archiwum Prowincji Bernardynów w Krakowie (dalej: APBK) Rkps I-a-4: Kronika klasztoru oo. Bernardynów w Krakowie od 1904 r., s. 147-148.

${ }^{4}$ Początki krakowskiego konwentu bernardynów zwiazane sq̨ z przybyciem do Polski w 1453 r., na zaproszenie króla Kazimierza Jagiellończyka i biskupa krakowskiego Zbigniewa Oleśnickiego, sw. Jana Kapistrana. Fundatorem kościoła i klasztoru był biskup Oleśnicki. On też dokonał jego konsegracji 8 IX 1453 r. Świątynia otrzymała wezwanie św. Bernardyna ze Sieny. Klasztor przez długie lata stanowił centralny ośrodek życia zakonnego najpierw Prowincji Polskiej powstałej w 1517 r., a po roku 1628 także Małopolskiej wyodrębnionej w wyniku podziału dotychczasowej jednej prowincji na cztery - wielkopolska, ruska, litewska oraz wyżej wspomnianą. Prowincjałowie małopolscy przebywali tu do 1795 r., a więc do czasu zajęcia Krakowa przez Austriaków - K. K a n t a k, Bernardyni polscy, t. 1, Lwów 1933, s. 2; H. E. W y c z a w s k i OFM, Kraków - św. Bernardyn, [w:] Klasztory bernardynskie..., s. 154, 155, 160; K. G rudzińs k i OFM, Kult św. Józefa opiekuna Najświętszej Rodziny u bernardynek i bernardynów w Polsce, Kraków 1985, s. 1 (mps w posiadaniu APBK sygn. 200).

${ }^{5}$ H. E. W y c z a w s k i OFM, Kraków..., s. 159 n.; K. K a n t a k, Dzieje krakowskich bernardynów w zarysie, [w:] K. Kantak, J. S zablow ski, J. Ż a rn e cki, Kościót i klasztor oo. Bernardynów w Krakowie, Kraków 1938, s. 64. 
Ojcowie zmuszeni zostali wówczas do przyjęcia obowiązków na rzecz wojska. Obok poboru braci w szeregi walczących, klasztor poniósł wiele szkód moralnych i materialnych $w$ zwiazku $z$ funkcjonowaniem $w$ jego murach od początku wojny szpitala wojskowego ${ }^{6}$. Na skutek jego lokalizacji zlikwidowane zostało kolegium dla młodzieży, które przygotowywało do dalszego kształcenia w ramach studium zakonnego, wymaganego od kandydatów do klasztoru. Obok tego chorzy i wojskowi dokonywali dewastacji cennych zbiorów bibliotecznych ${ }^{7}$. Ponoszono straty także $\mathrm{w}$ wyniku zawłaszczeń i rujnowania pomieszczeń klasztornych wykorzystywanych na sale szpitalne. Stąd też istniała konieczność przeprowadzenia remontu popadłych w ruinę zabudowań. Przewidywane koszty przekraczały jednak możliwości konwentu. Toteż starano się wyegzekwować od władz wojskowych zobowiązania przejęte przez rząd polski po władzach austriackich. Przewidywały one odrestaurowanie pomieszczeń zajmowanych przez szpital wojskowy. Liczono, że łatwiej będzie to uzyskać, jeżeli wynajmie się owe pomieszczenia na powrót wojsku. W wyniku porozumienia ulokowano tutaj z dniem 15 stycznia 1919 r. menaż oficerską. Niestety już wkrótce stało się jasne, że nie przyniesie to spodziewanych rezultatów, gdyż wszelkie składane interpelacje nie przynosiły oczekiwanych skutków. W tej sytuacji nowo mianowany kustosz konwentu bł. o. Anastazy Jakub Pankiewicz ${ }^{10}$ postanowił rozpoczać renowację korzystając $\mathrm{z}$,własnych" środków. Co prawda 17 lutego 1921 r. zwrócono się do władz naczelnych państwa $\mathrm{z}$ żądaniem przyznania odszkodowania za poniesione $\mathrm{w}$ czasie wojny szkody, ale też w międzyczasie, nie bacząc na decyzje rządu, przystapiono do prac porząkowych ${ }^{11}$. Prace prowadzono na zewnątrz i od wewnątrz budynku. W tym czasie poddano renowacji wielki ołtarz, w którym na powrót umieszczono barokowe kolumny usunięte w czasie remontu przeprowadzonego $\mathrm{z}$ początkiem XIX w. Odnowiono także mieszczący się w nim obraz Franciszka

\footnotetext{
${ }^{6}$ APBK Rkps I-a-4: Kronika..., s. 70, 146.

${ }^{7}$ Tamże, s. 147, 149.

${ }^{8}$ Tamże, s. $150,152$.

${ }^{9}$ Tamże, s. $142 \mathrm{n}$.
}

${ }^{10}$ Anastazy Jakub Pankiewicz urodził się 9 VII 1882 r. w rodzinie rolniczej. Jego rodzicami byli Tomasz i Tekla z domu Lenio. Młodość spędził we wsi Nowotaniec z Nagórzanami k. Sanoka. Do zakonu wstapił w roku 1900. W latach 1903-1907 odbył studia teologiczne w Krakowie $\mathbf{i}$ we Lwowie. W czasie wojny pelnił funkcje kapelana wojskowego. W latach 1919-1930 był gwardianem konwentu krakowskiego, gdzie przeprowadzil remont kościoła. Był inicjatorem budowy i pierwszym przełożonym klasztoru bernardyńskiego w Lodzi (od 1932 r.) oraz założycielem Zgromadzenia ss. Antonianek od Chrystusa Króla. Był znanym duszpasterzem. Zamordowany w Dachau 20 V 1942 r. Beatyfikowany przez papieża Jana Pawła II, jako jeden ze 108 męczenników za wiarę z czasów II wojny światowej (13 VI 1999 r.). C. G $\mathrm{n}$ i e c k i OFM, Stowo wstepne do: Btogostawiony Anastazy Jakub Pankiewicz bernardyn $i$ dzieje jego łódzkiej fundacji, pod red. W. F. M u r a w c a OFM, Kraków 1999, s.7; W. F. M u r a w i e c OFM, Życie, dziatalność, męczenistwo bt. Anastazego Jakuba Pankiewicza OFM, [w:] Błogosławiony Anastazy Jakub Pankiewicz bernardyn i dzieje jego łódzkiej fundacji, pod red. W. F. Murawca OFM, Kraków 1999, s. 9, 10 n.; H. E. W y c z a w sk i OFM, Pankiewicz Jakub Anastazy, [w:] Polski Stownik Biograficzny, pod red. E. Rostworowskiego, t. 25. Wrocław 1980, s. $129,130$.

${ }^{11}$ APBK Rkps I-a-4: Kronika..., s. 144, 178. 
Lekszyckiego OFM „Ostatnia Wieczerza”12. Ponadto ustawiono w kościele nowe stalle i usunięto niektóre ołtarze $z$ naw bocznych św. Bonawentury i św. Piotra z Alkantary. Świątynia została też gruntownie odmalowana. Na zewnątrz dokonano remontu frontonu oraz wykonano szereg prac murarskich w celu wzmocnienia murów i fundamentów kościoła. Remont generalny ukończono po dwóch latach, w grudniu $1927 \mathrm{r} .{ }^{13}$ Niemniej jednak prace były kontynuowane jeszcze przez jego następców - o. Floriana Rogowskiego (1930-1937) oraz o. Kaliksta Stuligłowe (1937-1939) ${ }^{14}$.

Troska o klasztor krakowski nie przeszkodziła o. Pankiewiczowi podjąć się zadania, które miało ogromne znaczenie dla całej zakonnej prowincji. By sprostać jej potrzebom podją on starania o powołanie w Krakowie Kolegium Serafickiego. Kapituła prowincjalna, która zebrała się w Kalwarii Zebrzydowskiej w roku 1927 przystała na popierana przez o. Pankiewicza propozycje i zdecydowała podjąć budowę na Przegorzałach w Krakowie domu zakonnego, by następnie przenieść tam Kolegium radecznickie powołane w $1922 \mathrm{r}^{15}$. Niestety na przeszkodzie $\mathrm{w}$ realizacji przedsięwzięcia stanął Urząd Ziemski, który nie wyraził zgody na zakup gruntu. Ze względu na negatywną odpowiedź Ministerstwa Reform Rolnych na złożoną przez konwent krakowski interpelację, kapituła prowincjalna odbyta w 1930 r. w Leżajsku zaniechała budowy Kolegium w Krakowie ${ }^{16}$.

Życie codzienne klasztoru podobnie jak wiekach poprzednich upływało jednak nie tylko na troskach o dobro wspólnoty klasztornej czy też prowincji, ale także na angażowaniu się w pracę społeczną dla dobra wiernych Kościoła Katolickiego. Skierowana ona była w dużej mierze na działalność charytatywną oraz piśmienniczą jednak głównym zadaniem, jakie postawili sobie bernardyni stało się duszpasterstwo ${ }^{17}$. Od wieków, bowiem przywiązywali oni szczególną wagę do tego rodzaju posługi i przez nią przede wszystkim starali się realizować Boże posłannictwo. Takie nastawienie towarzyszyło im również przez całe dwudziestolecie międzywojenne. Swe obowiązki wypełniali wówczas zarówno w stosunku do wiernych gromadzących się w ich kościele, jak i niosąc pomoc $w$ innych zakonnych i diecezjalnych ośrodkach duszpasterskich.

${ }^{12}$ Tamże, s. $302 \mathrm{n}$.

${ }^{13}$ Tamże, s.306 n; Rkps RGP-f-7: Akta dotyczące klasztorów w Kole i Krakowie na Stradomiu. (1750-1947), s. 1016.

${ }^{14}$ APBK Rkps I-a-4; Kronika ..., s. 339, 352; APBK Rkps I-a-9: Fragmenty kroniki oo. Bernardynów w Krakowie (1930-1952), s. 3, 7. ka..., s. 308.

${ }^{15}$ K. K a n t a k, Bernardyni polscy, t. 2, Lwów 1933, s. 580; APBK Rkps I-a-4: Kroni-

${ }^{16}$ Ostatecznie Kolegium Serafickie powstało wraz z rezydencją zakonną w Lodzi, w dzielnicy Doły, również z inicjatywy bł. o. Pankiewicza. Budowę prowadzono w latach 1932-1937 - W. F. M u r aw i e c OFM, Życie, dziatalność, męczeństwo bł. Anastazego..., s. 11; APBK Rkps I-a-4: Kronika..., s. 312, 315.

${ }^{17}$ H. E. W y c z a w s k i OFM, Bernardyni polscy, t. 3, (1772-1946), Kalwaria Zebrzydowska 1992, s. 396, 398; W. Biegus OFM, Dziatalność charytatywna oo. Bernardynów w Polsce, „Dzwonek Trzeciego Zakonu” R. 45: 1931, nr 6-7, s. 221, 223; APBK Rkps I-c-18: Księga protokołów sesji dyskretorium klasztoru oo. Bernardynów w Krakowie. (1932-1966), s. 16. 
DUSZPASTERSTWO W OBREBIE WŁASNEGO KOŚCIOŁA

Bernardyni prowadząc duszpasterstwo przy własnej świątyni czynili to na różne sposoby. Między innymi poprzez konfesjonał i ambonę. Wspomnieć przy tym należy, że od czasów przełożeństwa o. Floriana Rogowskiego wprowadzono po Prymarii ${ }^{18}$ głoszenie Słowa Bożego w niedziele i święta oraz codzienną spowiedź świętą ${ }^{19}$. Modlono się również za zmarłych i dobrodziejów klasztoru. W ich intencjach odprawiano także Msze św. fundacyjne. Zmarłym poświęcony był szczególnie miesiąc listopad oraz nabożeństwa kwartalne. Te ostatnie, choć miały charakter modlitw wewnątrzzakonnych, odbywały się przy udziale wiernych oraz członków Trzeciego Zakonu ${ }^{20}$. Dla uzmysłowienia zaś wiernym rangi prowadzonej przez Kościół działalności misyjnej organizowano dni i niedziele misyjne w czasie, których odprawiano nabożeństwa $\mathrm{z}$ okolicznościowym kazaniem ${ }^{21}$. Z kościoła stradomskiego odbywały się również pielgrzymki. Członkowie bractw przykościelnych, Trzeciego Zakonu Franciszkańskiego oraz wierni podążali głównie do sanktuariów maryjnych w Kalwarii Zebrzydowskiej i Częstochowie, ale także do Mogiły k. Krakowa i Leżajska ${ }^{22}$. Nie należy również zapomnieć o duszpasterstwie okolicznościowym jak na przykład obchody jubileuszowe, nabożeństwa o pokój czy tygodnie miłosierdzia ${ }^{23}$.

Nieodłącznym elementem duszpasterstwa było oczywiście sprawowanie Mszy świętej i nabożeństw paraliturgicznych dla oddawania czci Bogu, Najświętszej Marii Pannie oraz świętym. Kierowano się przy tym powszechnym kalendarzem kościelnym oraz bernardyńskim kalendarzem liturgicznym. Najważniejszym dniem dla chrześcijanina jest niedziela, toteż starano się to uzewnętrznić przez uroczyste formy praktyk religijnych ${ }^{24}$. W tygodniu zaś każdy dzień był poświęcony $\mathrm{w}$ sposób szczególny jednemu ze świętych franciszkańskich. Wyjątkiem był piątek, kiedy to oddawano cześć Sercu Jezusowemu oraz sobota poświęcona Najświętszej Maryi Pannie ${ }^{25}$.

Ojcowie bernardyni obchodzili również uroczystości doroczne. Kierując się porządkiem roku liturgicznego $\mathrm{z}$ największych uroczystości należałoby wymienić Narodzenie Pańskie. W czasie tych świąt odprawiano Msze św.

\footnotetext{
${ }^{18}$ Msza św. poranna.

${ }^{19}$ APBK Rkps I-a-9: Fragmenty kroniki ..., s. 5.
}

${ }^{20}$ Modlitwy i zwyczaje oo. Bernardynów. Kalwaria Zebrzydowska 1987, s. 250; APBK Rkps I-d-41: Porządek nabożeństw w kościele oo. Bernardynów w Krakowie z roku 1931, s. 40 n; Rkps I-d-3: Missae fundatae pro sacristia conventus Cracoviensis ad S. Bernardinum Ordinis Fratrum Minorum ab a. D. 1910, passim.

${ }^{21}$ APBK Rkps I-c-6: Księga kurend klasztoru oo. Bernardynów w Krakowie, (1909$-1946)$, s. 187, 191.

${ }_{22}$ APBK Rkps I-a-9: Fragmenty kroniki ..., s. 2; Rkps I-a-4: Kronika ..., s. 325 n.

${ }^{23}$ APBK Rkps I-a-4: Kronika ...,s. 326; Rkps I-a-5: Kronika klasztoru Braci Mniejszych oo. Bernardynów w Krakowie od 19 maja 1936 r., s. 4; Rkps I-d-29: Akta dotyczące kultu, nabożeństw i duszpasterstwa w kościele oo. bernardynów w Krakowie. (1510-1948), s. 433; Rkps I-d-43: Ogloszenia kościelne w klasztorze bernardynów w Krakowie. (1937-1939), s. 28.

\footnotetext{
${ }^{24}$ APBK Rkps I-d-41: Porządek nabożeństw..., s. 3, 4.

${ }^{25}$ Tamże, s. 2.
} 
przed szopką betlejemską w kaplicy bł. Szymona z Lipnicy. Najważniejszym świętem chrześcijańskim jest uroczystość Wielkiej Nocy. Poprzedzona jest ona okresem Wielkiego Postu w czasie, którego odbywały się u oo. Bernardynów rekolekcje połączone ze spowiedzią wielkanocną. W ciagu roku obchodzono również święta związane z kultem Pana Jezusa Chrystusa i Jego Matki oraz świętych i błogosławionych franciszkańskich - św. Franciszka z Asyżu, św. Antoniego z Padwy, św. Bernardyna ze Sieny, św. Jana Kapistrana, bł. Władysława z Gielniowa, św. Jana z Dukli, bł. Szymona z Lipnicy oraz św. Elżbiety Węgierskiej, patronki Trzeciego Zakonu. Prócz tego czczono tutaj także św. Józefa oraz św. Annę. Nabożeństwa doroczne połączone były z możliwością uzyskania odpustu zupełnego i oddania czci relikwiom przez ucałowanie. Przy czym relikwie podawano do ucałowania również w czasie nabożeństw tygodniowych. W związku z tym szczególnymi formami duszpasterstwa stały się liczne wystawienia Najświętszego Sakramentu oraz procesje. Ku ich czci odprawiano również nabożeństwa majowe, różańcowe, nieszpory, droge krzyżową oraz gorzkie żale ${ }^{26}$.

Bardzo istotnym dla rozwoju kultu był fakt, że Bernardyni posiadali relikwie wszystkich świętych odbierających cześć w ich kościele, a także relikwie Krzyża Świętego. Najliczniejsze były relikwie bł. Szymona z Lipnicy. W skarbcu kościelnym znajdował się duży relikwiarz z czaszką Świętego oraz płaszcz zakonny i pasek używany przez niego do Mszy św. ${ }^{27}$ Warto również zauważyć, że kult ten mógł być sprawowany przed specjalnie poświęconymi tym świętym ołtarzami. W kościele bernardyńskim znajdowały się również ołtarze poświęcone Matce Bożej i Jej Synowi. Najsłynniejszym maryjnym ołtarzem był ten z obrazem Niepokalanego Poczęcia Najświętszej Marii Panny ${ }^{28}$. Pan Jezus zaś odbierał swą cześć w szczególności przy ołtarzach poświęconych Drodze Krzyżowej - ołtarz Ukrzyżowania i ołtarz Upadku P. Jezusa oraz ołtarz Ecce Homo, a także przy głównym ołtarzu, w którym znajdował się obraz „Wieczerza Pańska” namalowany przez Franciszka Lekszyckiego OFM. Ponad to na uwage zasługuje fakt, iż w świątyni tej znajdowała się kaplica Matki Bożej Bolesnej, św. Anny i bł. Szymona z Lipnicy ${ }^{29}$.

Przyczynkiem do rozwoju kultu były również liczne pamiątki związane $\mathrm{z}$ osobą świętego. Przykładem ich może tu być księga zapisana ręką bł. Szymona $\mathrm{z}$ Lipnicy, przechowywana w bibliotece klasztornej. $\mathrm{Z}$ osobą jego wiąże się również przekonanie o cudownych właściwościach wody zaczerpniętej ze

${ }^{26}$ APBK Rkps I-d-41: Porządek nabożeństw..., passim; Rkps I-d-42: Porządek nabożeństw w kościele oo. Bernardynów w Krakowie z roku 1935, s. 16.

${ }^{27}$ Kolebka zakonu oo. Bernardynów. „Dzwonek Trzeciego Zakonu”. R. 51: 1936, nr 7-8, s. 204; APBK Rkps I-g-12: Inwentarz kościoła i klasztoru Braci Mniejszych oo. Bernardynów w Krakowie. (1937), s. 6.

${ }^{28}$ W roku 1932 obchodzono jubileusz 550-lecia sprowadzenia cudownego obrazu do kościoła stradomskiego. - APBK Rkps I-a-4: Kronika..., s. 338; Rkps I-g-12: Inwentarz..., s. 2-3.

${ }^{29}$ J. Ż a r n e c k i, Zabytki krakowskiego kościoła bernardynów, [w:] K. K a n t a k, J. Szblowski, J. Żarnecki, Kościót $i$ klasztor oo. Bernardynów w Krakowie, Kraków 1938, s. 125; APBK Rkps I-g-12: Inwentarz..., s. 3, 6. 
studzienki przyklasztornej nazywanej jego imieniem ${ }^{30}$. Nawiązując do tego należy wspomnieć, że w ogóle wierzono w przesłania o cudach czynionych za pośrednictwem świętych między innymi właśnie bł. Szymona, ale także św. Antoniego Padewskiego i św. Jana z Dukli ${ }^{31}$. Powszechnie również uznawano cudowność obrazu Niepokalanego Poczęcia Najświętszej Maryi Panny znajdującego się w kościele na Stradomiu ${ }^{32}$.

Wyjątkową formą oddawania czci Zbawicielowi Naszemu Jezusowi Chrystusowi, Jego Matce oraz świętym i błogosławionym były organizowane, czasem bardzo uroczyste, obchody jubileuszowe. Dwa pierwsze związane były ze św. Franciszkiem z Asyżu. W roku 1924 przypadała 700 rocznica jego stygmatyzacji na Górze Alwerni, a w 1926 r. 700-lecie śmierci Świętego obchodzone w Krakowie w sposób bardzo uroczysty, w dniach od 1 do 4 lipca ${ }^{33}$. Uroczysty charakter miały także obchody 700-lecia śmierci św. Antoniego z Padwy. W Krakowie wypadły one od 3 do 5 lipca 1931 r. ${ }^{34}$ W tym też roku obchodzono 600-lecie urodzin św. Elżbiety Węgierskiej, patronki Trzeciego Zakonu. Czciciele tej Świętej mieli jeszcze możność uczczenia jubileuszu jej kanonizacji, ale to miało miejsce trochę później, bo w roku $1936^{35}$. W roku 1932 obchodzono 450. rocznicę zgonu bł. Szymona z Lipnicy, a w rok później 200-lecie beatyfikacji św. Jana z Dukli. Rok 1933 był jednak zdominowany obchodami jubileuszowymi Odkupienia Ludzkości przez Syna Bożego. Uroczystości z tej okazji odbywano w całym Kościele powszechnym ${ }^{36}$.

Bardzo ważne dla pracy nad duchowym rozwojem wiernych, w niektórych przypadkach przyczyniającym się również do propagowania kultu świętych było istnienie przy krakowskim konwencie Trzeciego Zakonu Franciszkańskiego oraz bractw i stowarzyszeń.

Trzeci Zakon Franciszkański, założony przez św. Franciszka z Asyżu, przy współpracy z kardynałem Hugolinem, późniejszym papieżem Grzegorzem IX w 1221 r. pojawił się w Krakowie w związku z przybyciem tu Jana Kapistrana. Jego pierwsza siedziba znajdowała się w pobliżu kościoła św. Mikołaja. Po wyjeździe założyciela III Zakon istniał przez ponad trzy wieki, po czym po rozbiorach zaczął podupadać. W wieku XIX doszło niemal do całkowitego wygaśnięcia jego działalności. Jednak po ukazaniu się encykliki papieża Leona XIII poświęconej właśnie III Zakonowi prowincjał Norbert Goli-

${ }^{30}$ Kolebka zakonu..., s. 203 n.

${ }^{31}$ Glos św. Antoniego, „Dzwonek Trzeciego Zakonu” R. 40: 1926, nr 6, s. 375; Laski i cuda bł. Jana z Dukli, „Dzwonek Trzeciego Zakonu” R. 47: 1933, nr 1, s. 20; Laski doznane za przyczyna bl. Szymona z lipnicy w latach 1931-1936, „Dzwonek Trzeciego Zakonu” R. 51: 1936, nr 7-8, s. 218; APBK Rkps I-e-8: Akta dotyczące bł. Szymona z Lipnicy i jego kultu. (1921-1956), s. 1, 3.

${ }^{32}$ APBK Rkps RGP-k-82: Teki Bogdalskiego, t. 65, s. 65, 67.

${ }^{33}$ Pamiatka jubileuszowa 700 rocznicy śmierci św. Franciszka z Asyżu 1226-1926. Kraków 1928, s. 47, 71; APBK Rkps I-a-4: Kronika..., s. 304; Rkps I-c-6: Księga kurend..., s. 95 n.

${ }^{34}$ F. K ę d z i e r s k i OFM, Polska a Święty z Padwy (o obchodach 700-lecia), „Dzwonek Trzeciego Zakonu" R. 45: 1931, nr 9, s. 271 n, 273 n; APBK Rkps I-a-14: Kronika..., s. 326 n.

${ }_{35}$ APBK Rkps I-a-4: Kronika..., s. 329, 373.

${ }^{36}$ Tamże, s. 337, 348; APBK Rkps I-c-6: Księga kurend..., s. 187. 
chowski polecił ponownie go erygować. W sposób kanoniczny dokonał tego o. Czesław Bogdalski ${ }^{37}$ w roku 1883, zostając jednocześnie jego pierwszym dyrektorem $^{38}$.

Franciszkański Zakon Świeckich nie został powołany wyłącznie dla celów dewocyjnych. Jego zadaniem jest również rozwijanie działalności społecznej, która dokonuje się przez niesienie pomocy i poświęcenie się dla bliźniego zgodnie z duchem braterstwa oraz wzajemnej miłości. Stanowi to siłe tercjarstwa jaką czerpie ono z Ewangelii i serafickich wzorów św. Franciszka oraz jego uczniów $w^{39}$.

W latach 1918-1939 tercjarze z krakowskiego konwentu bernardynów prężnie rozwijali swą działalność i przeżywali wiele uroczystości zakonnych i ogólnokościelnych. Życie religijne wspólnoty pielęgnowane było poprzez doroczne rekolekcje, pielgrzymki, a także prasę (głównym wydawnictwem prasowym zalecanym tercjarzom do czytania był miesięcznik „Dzwonek Trzeciego Zakonu") i działalność teatralną ${ }^{40}$. Ksztaltowaniu poziomu religijnego i intelektualnego miała też służyć założona $\mathrm{z}$ początkiem lat trzydziestych biblioteka zakonna ${ }^{41}$.

Zwracano także uwage na rozwój moralny i materialny wspólnoty. $\mathrm{W}$ tym celu powołano w $1926 \mathrm{r}$. Stowarzyszenie Tercjarskie pod wezwaniem św. Elżbiety zwane potocznie „Schroniskiem”, a w 1936 r. kółka tercjarskie. Należy tu jednak zauważyć, że „Schronisko" obok niesienia pomocy członkom kongregacji miało udzielać jej również sierotom i ubogim dzieciom poprzez zorganizowanie dla nich ochronki. Prócz tego działalność charytatywna rozwijana była w ramach Sekcji Miłosierdzia. Nie zapomniano także o potrzebach ostatecznych. W 1930 r. z inicjatywy bł. Anastazego Pankiewicza, ówczesnego dyrektora miejscowej kongregacji, powołana została do istnienia Kasa Pogrzebowa. Jej członkowie, którymi zostać mogli tak tercjarze jak i pozo-

${ }^{37}$ Czesław Ignacy Bogdalski OFM urodził się we Lwowie w 1853 r. w rodzinie rzemieślniczej jako syn Joachima i Kunegundy z Krogulskich. Do bernardynów wstapił w $1870 \mathrm{r}$. i odbył nowicjat w Kalwarii Zebrzydowskiej. Teologię studiował we Lwowie oraz w tarnowskim Wyższym Seminarium Duchownym. W 1873 r. złożył profesję solemną a w rok później przyjął święcenia kapłańskie. Znany był jako propagator III Zakonu, redaktor „Dzwonka III Zakonu" oraz historyk, misjonarz, rekolekcjonista, kaznodzieja. Zmarł w Krakowie w 1935 r. - K. Gru d z iń s k i OFM, Bogdalski Czestaw Ignacy, [w:] Stownik Polskich Pisarzy Franciszkańskich, pod red. H. E. Wyczawskiego OFM, Warszawa 1981, s. 61 n; K. K a n t a k, Bogdalski Czestaw Ignacy, [w:] Polski Stownik Biograficzny, pod red. W. Konopczyńskiego, t. 2. Kraków 1936, s. 188; K. K a n t a k, Bernardyni polscy, t. 2, s. 570-571.

${ }^{38}$ P. S te i n OFM, Trzeci Zakon Franciszkański, przekł. J. Kędzior OFM. Lwów 1933, s. 13 n; O Trzecim Zakonie Franciszkańskim, „Dzwonek Trzeciego Zakonu” R. 49: 1939, nr 7-8, s. 200; APBK Rkps RGP-k-82: Teki..., t. 65, s. 148.

${ }^{39}$ Pamiętnik Ogólnopolskiego Kongresu tercjarskiego odbytego w Krakowie z okazji 700-letniego jubileuszu zatożenia III Zakonu. św. o. Franciszka, 1221-1921, Częstochowa 1922, s. $177 \mathrm{n}$.

${ }^{40}$ K. M a n i k, Pielgrzymka Jubileuszowa tercjarzy polskich do Rzymu w roku 1925, „Dzwonek trzeciego Zakonu” R. 39: 1925, nr 5, s. 317; APBK Rkps I-f-36: Księga protokołów III Zakonu św. Franciszka przy kościele oo. Bernardynów w Krakowie (1930-1959), s. 1, 22; APBK Rkps I-c-6: Księga kurend..., s. 304.

${ }^{41}$ APBK Rkps I-f-36: Księga protokołów III Zakonu ..., s. 1, 53. 
stali wierni Kościoła, mogli zapewnić sobie pochówek i modlitwę po śmierci. Nie stroniono też od wspierania pracy misyjnej I Zakonu angażując się na jej rzecz poprzez coroczne składki ${ }^{42}$.

Starano się również rozwijać wspólnotę pod względem liczebnym. Toteż w 1934 r. podjęto decyzję o możliwości powołania przy klasztorze kongregacji męskiej. Obwarowano to jednak koniecznością przystapienia do tercjarstwa większej liczby mężczyzn ${ }^{43}$. Ojcowie dyrektorzy zachęcali również do propagowania III Zakonu wśród młodzieży, zwłaszcza, że pod koniec lat trzydziestych zauważono spadek liczby kandydatów do tutejszej wspólnoty. Z problemem tym może wiązać się fakt, że w roku 1936 zlikwidowano tutaj Stowarzyszenia Młodzieży Tercjarskiej ${ }^{44}$.

Obok codziennych starań o sprostanie swemu powołaniu tercjarze ze Stradomia przeżywali także wiele ważnych dla siebie wydarzeń i uroczystości. Należy tu przede wszystkim wymienić dwa wielkie ogólnopolskie kongresy tercjarskie odbyte w Krakowie. Pierwszy z nich miał miejsce w dniach od 2-4 sierpnia $1921 \mathrm{r}$. i był w ogóle pierwszym tego typu kongresem w historii tercjarstwa. Uroczystości te zbiegły się z obchodami 700-lecia założenia III Zakonu przez św. Franciszka z Asyżu. Inicjatorem kongresu był o. Czesław Bogdalski, który pozyskał dla niego przychylność Kurii Metropolitarnej ${ }^{45}$. Drugi kongres odbył się w roku 1926 i związany był z obchodami 700-lecia śmierci św. Franciszka z Asyżu. W wydanej z okazji tejże rocznicy encyklice Rite exspiatis papież Pius XI mówił miedzy innymi, że uroczystości te mają być uwieńczeniem obchodzonego w Rzymie jubileuszu roku $1925^{46}$.

Ważnym wydarzeniem dla krakowskiego tercjarstwa było zawiązanie się 24 lutego 1927 r. Tercjarskiej Rady Miejscowej. Statut Rady, zatwierdzony został przez Radę Główną Trzeciego Zakonu z siedzibą w Krakowie, która powstała decyzją I Ogólnopolskiego Kongresu Tercjarskiego odbytego w roku 1921. Zadaniem jej było popieranie i regulowanie życia tercjarskiego w Polsce. Nadmienić należy również, że pierwszym prezesem Tercjarskiej Rady Miejscowej został bł. o. Anastazy Pankiewicz, z konwentu stradomskiego ${ }^{47}$.

Bez znaczących uroczystości nie obyły się też lata trzydzieste XX wieku. Obok obchodów jubileuszowych związanych ze św. Antonim i św. Elż-

${ }^{42}$ APBK Rkps I-f-4: Akta dotyczące III Zakonu św. Franciszka i bractw przy kościele bernarđynów w Krakowie (1930-1966), s. 63, 65; Rkps I-f-35: Kasa pogrzebowa przy kościele oo. bernardynów dla członków III Zakonu (1930-1944), s. 1; Rkps I-f-36: Księga protokołów III Zakonu..., s. 21, 29, 47.

${ }^{43}$ APBK Rkps I-f-36: Księga protokołów III Zakonu ..., s. 30.

${ }^{44}$ Tamże, s. 44, 56.

${ }^{45}$ Pamiętnik Ogólnopolskiego Kongresu tercjarskiego..., s. 4 n; Pierwszy Kongres III Zakonu w Polsce, „Dzwonek trzeciego Zakonu” R. 35: 1921, nr 9, s. 7,9.

${ }^{46}$ Pamiqtka jubileuszu 700 rocznicy śmierci św. Franciszka..., s. 71; Encyklika O. Ś Piusa XI o św. Franciszku z Asyżu w siedemsetnq rocznice jego śmierci. „Dzwonek Trzeciego Zakonu" R. 40:1926, nז 7, s. 395.

${ }^{47} \mathrm{Cz}$. B og dals k i, Organizacja $i$ działalność III Zakonu św. Franciszka, Kraków 1926, s.147; Rezolucje Kongresu tercjarskiego, „Dzwonek trzeciego Zakonu” R. 35: 1921, nr 10, s. 18; Kronika, „Dzwonek trzeciego Zakonu” R. 41: 1927, nr 4, s. 253, 254. 
bieta, patronką Trzeciego Zakonu ${ }^{48}$, odbyto w Krakowie kolejny kongres, choć tym razem o zasięgu tylko archidiecezjalnym. Polączony on byl $z$ dorocznym Zjazdem Rady Głównej Trzeciego Zakonu i odbył się w dniach 14-17 czerwca 1927 r. $^{49}$

Obok Franciszkańskiego Zakonu Świeckich na Stradomiu istniało jeszcze kilka bractw i stowarzyszeń. Zrzeszały one osoby świeckie dla celów dewocyjnych. Najprężniej działającym bractwem w dwudziestoleciu międzywojennym było Arcybractwo Niepokalanego Poczęcia Najświętszej Maryi Panny. Powołane zostało 7 XII 1736 r. przez Jana Kapistrana Połanieckiego. Od 1750 roku na mocy breve papieża Benedykta XIV posiadało odpusty zupełne i cząstkowe ${ }^{50}$. W latach dwudziestych obecnego wieku rozwijało się ono, jak się zdaje dość intensywnie. Obok Białej Koronki i Szkaplerza Niepokalanego Poczęcia obejmowało ono Stowarzyszenie Młodzieńców, które od 1933 r. miało własny chór ${ }^{51}$. Życie wewnętrzne Arcybractwa upływało na wspólnych modlitwach takich jak nieszpory czy koronka do Matki Bożej oraz na organizowanych przez siebie pielgrzymkach do sanktuariów maryjnych. Ponadto członkowie bractwa uczestniczyli w Kongresie Mariańskim organizowanym w Krakowie w dniach 11-12 kwietnia 1931 r., zaś w 1936 r. obchodzili jubileusz 200-lecia ustanowienia Arcybractwa przy tutejszym kościele ${ }^{52}$.

Prócz Arcybractwa Niepokalanego Poczęcia NMP w interesującym nas okresie działały na Stradomiu jeszcze inne bractwa, o których jednak nic ponad to nie można powiedzieć. Do nich należało Bractwo Różańcowe oraz Bractwo św. Antoniego. Wspomina się też niekiedy o Stowarzyszeniu Drogi Krzyżowej. Niestety inaczej jest $\mathrm{z}$ tradycyjnym już dla bernardynów Bractwem św. Anny. Powołane ono zostało na Stradomiu w roku 1671 przez Arcybractwo tegoż imienia w Warszawie. Nic jednak nie wskazuje na to, by przetrwało ono do dwudziestych i trzydziestych lat XX wieku ${ }^{53}$.

${ }^{48}$ Zob. s. 8.

${ }^{49}$ F. K e d z i e r s k i OFM, Doroczny Zjazd Rady Gt. T. Z. i Kongres tercjarski archidiecezji krakowskiej, „Dzwonek trzeciego Zakonu” R. 50: 1935, nr 7--8, s. 224.

${ }^{50}$ APBK Rkps I-f-8: „Księga żywota, to jest katalog braci i sióstr Bractwa Niepokalanego Poczęcia Najświętszej Maryi Panny do kościoła stradomskiego oo. Obserwantów Franciszka Świętego przez o. Jana Kapistrana Polanieckiego Kustosza aktualnego roku P. 1736 dnia 7 grudnia wprowadzonego", s. 9; Ustawy Bractwa Niepokalanego Poczęcia NMP przy kościele św. Bernardyna Sieneńskiego na Stradomiu w Krakowie zatwierdzone przez książęco-biskupi Konsystorz w Krakowie r. P. 1900, s. 23.

${ }^{51}$ APBK Rkps I-f-14: Księga protokołów z posiedzeń Bractwa Niepokalanego Poczęcia NMP przy kościele oo. bernardynów w Krakowie. (1894-1948), s. 64; Rkps I-f-21: Księga wpisowa do Białej Koronki i Szkaplerza Niepokalanego Poczęcia NMP przy kościele oo. bernardynów w Krakowie od 1902 r., s. 81 n.

${ }_{52}$ APBK Rkps I-f-14: Księga protokołów z posiedzeń Bractwa Niepokalanego Poczęcia NMP..., s. 42, 53; Rkps I-a-5: Kronika klasztoru..., s.4.

${ }_{53}$ Schematismus Ord. Fatrum Minorum S. P. N. Francisci almae Provinciae Immacultae Conceptionis BMV in Polonia... pro anno Domini 1939. Radecznica 1939, s. 24; APBK Rkps I-f-4: Akta dotyczące III Zakonu św. Franciszka i bractw..., s. 739, 761; APBK Dok. 73: Arcybractwo św. Anny w Warszawie, promotorowie, seniorzy, członkowie, za zgodą biskupa miejsca, ustanawiają Bractwo św. Anny w kościele Bernardynów na Stradomiu w Krakowie i dopuszczają jego członków do odpustów nadanych przez papieża Sykstusa V. 
Na osobną uwagę zasługuje Franciszkański Związek Misyjny powołany w zakonnej prowincji polskiej decyzją kapituły prowincjalnej z dnia 17-19 lipca $1924 \mathrm{r}$. Uczyniono to na polecenie generała zakonu o. Bernardyna Klumpera $\mathrm{z}$ roku 1922, który nakazał zaprowadzenie Związku w każdej prowincji i w każdym klasztorze. Związek Misyjny wydatnie różnił się od wyżej wymienionych bractw swoimi zadaniami. Celem jego było, bowiem nie tyle rozwijanie życia religijnego wiernych, co propagowanie oraz wspieranie modlitwą i jałmużną działalności misyjnej I Zakonu. Zgodnie ze Statutami siedzibą prowincjalną Związku był Lwów, zaś jego patronem - św. Jan z Dukli ${ }^{54}$.

\section{DUSZPASTERSTWO PROWADZONE POZA W LASNYM KOSCIOLEM}

Poprzednio szeroko omówiona została działalność duszpasterska krakowskich bernardynów, jaką prowadzili w okresie dwudziestolecia międzywojennego przy własnej świątyni. Podobnie jednak jak w wiekach wcześniejszych wykazywali oni w tym czasie wiele zaangażowania również na rzecz rozwoju wewnętrznego pozostałych wiernych Kościoła katolickiego, a także tych, którzy jeszcze do niego nie należeli. Ich posługa w tym zakresie miała bardzo różnorodny charakter i obejmowała szerokie kręgi ludzi zarówno stanu świeckiego jak i zakonnego.

Jednym $\mathrm{z}$ wielu zadań, jakich podjęli się bernardyni $\mathrm{z}$ krakowskiego konwentu było niesienie pomocy duszpasterzom diecezjalnym i zakonnym w pełnieniu obowiązków na terenie ich własnych parafii w zakresie zwyczajnych form kierownictwa duchowego. Chętnie sprawowana przez nich posługa sprzyjała zacieśnieniu kontaktów z obsługiwanymi przez nich wspólnotami wiernych do tego stopnia, że w wielu przypadkach stawały się one niemal tradycją. Należy przy tym zauważyć, że nie miało w tym względzie znaczenia samo położenie parafii. Co prawda wiele $\mathrm{z}$ nich znajdowało się na terenie Krakowa, ale były też takie, które czasem były znacznie od niego oddalone. W Krakowie wspomagali oni głównie wspólnoty parafialne pozostające pod opieką duszpasterską duchowieństwa zakonnego. W pierwszej kolejności należy tutaj wspomnieć o posłudze spełnianej w kościołach franciszkańskich Braci Mniejszych popularnie w Polsce zwanych reformatami, Braci Mniejszych Konwentualnych, zwanych popularnie franciszkanami, Braci Mniejszych Kapucynów oraz Sióstr Bernardynek. Należy tu jednak podkreślić, że istniała znaczna różnica charakteru duszpasterstwa prowadzonego przy świątyni sióstr w porównaniu do kościołów męskich gałęzi zakonu. W kościołach braci franciszkanów pomoc w czynnościach duszpasterskich skierowana była na wspólnotę świeckich wiernych, pozostających pod opieką duchową zakonników i miała charakter posługi okolicznościowej. Inaczej zaś miało się

${ }^{54}$ Patronem ogólnoświatowego Związku Misyjnego, którego siedziba znajdowała się w Rzymie, był św. Antoni z Padwy. - Zwiazek Misyjny Zakonu Braci Mniejszych (oo. Bernardynów) w Polsce. Statut. „Dzwonek trzeciego Zakonu”. R. 39: 1925, nr 1, s. 52-53. 
$\mathrm{z}$ duszpasterstwem prowadzonym $\mathrm{u}$ bernardynek. Klasztor ich był, zgodnie $\mathrm{z}$ wielowiekowa tradycja, kapelania ojców ze Stradomia ${ }^{55}$. Oznaczało to, więc że stanowił on ich stałą placówkę obsługiwaną przez delegowanego tam kapelana ${ }^{56}$. W okresie dwudziestolecia międzywojennego klasztor krakowski oddelegował do pełnienia funkcji kapelana u bernardynek z klasztoru św. Józefa, sześciu ojców. W latach 1918-1922 był nim o. Jan Kapistran Cieślik, po którym od 1923 do 1925 r. objął kapelanię o. Innocenty Kominek. Kolejnym duszpasterzem sióstr był o. Czesław Bogdalski. Pełnił on swoje obowiązki dość długo, bo od 1926 do 1933r., kiedy to zastapił go o. Wiktoryn Rudolf. Ten z kolei odwołany został w roku 1937, gdy kapelanem został ponownie o. Innocenty Kominek. Pełnił on te funkcje jednak tylko przez rok. W roku 1938 zastapił go o. Romuald Gustaw, który odszedł z kapelani już w roku 1939 na rzecz swego poprzednika ${ }^{57}$.

Pomimo tak znacznego zaangażowania krakowskich bernardynów w duszpasterstwo rodzin franciszkańskich należy zauważyć, że równie często i chętnie korzystali oni z zaproszeń do pracy $w$ świątyniach będących pod opieką zgromadzeń o odmiennym od franciszkańskiego charakterze życia wspólnotowego. Spośród nich wymienić należałoby przede wszystkim kościoły dominikanów, augustianów, oraz karmelitów, ale bywali także, choć jak można sądzić zdecydowanie rzadziej u kanoników regularnych, paulinów i misjonarzy. Sporadycznie natomiast posługiwali w obiektach sakralnych administrowanych przez duchowieństwo diecezjalne. Należy tu jednak wspomnieć o kanonicznym założeniu drogi krzyżowej w kaplicy Seminarium Diecezji Częstochowskiej, położonego w sąsiedztwie zabudowań klasztornych bernardynów. Aktu tego dokonał w dniu 31 stycznia 1932 r. ówczesny kustosz konwentu, o. Florian Rogowski ${ }^{58}$.

Zaangażowanie w pracę na rzecz rozwoju życia wewnętrznego wiernych Kościoła miasta Krakowa nie wpłynęło - jak się wydaje - na ograniczenie pracy duszpasterskiej stradomskich bernardynów poza murami miasta. Zawsze, kiedy tylko wymagała tego potrzeba chwili wyjeżdżali do różnych pa-

${ }^{55}$ Mowa tutaj o klasztorze Sióstr Bernardynek pod wezwaniem św. Józefa, usytuowanym przy ulicy Poselskiej. Został on ufundowany w roku $1645 \mathrm{z}$ inicjatywy siostry Teresy z domu Katarzyny Zadzikówny, z klasztoru św. Agnieszki w Krakowie, która chciała w ten sposób zaradzić uciążliwym w skutkach dla sióstr wylewom Wisły. Definitorium prowincji bernardyńskiej przystało na tę propozycję pod warunkiem, że konwent ów będzie zależny od kustosza konwentu bernardynów ze Stradomia. Siostry objęły nowy klasztor 11 sierpnia 1646 r. Ze względów majątkowych prymas Michał Poniatowski w roku 1787 zdecydował o zniesieniu klasztoru św. Agnieszki i przeniesieniu sióstr do klasztoru św. Józefa, co nastapiło w roku 1788.Podobne plany miał prymas również wobec krakowskiego konwentu koletek. O jego likwidacji zdecydowal jednak dopiero w roku 1820 Sejm Rzeczypospolitej Krakowskiej, uzasadniając swą decyzję brakiem funduszy na utrzymanie klasztoru. - R. G u s t a w OFM, Klasztor i kościót św. Józefa sióstr bernardynek w Krakowie, 1646-1946. Kraków 1947, s. 3, 38, 41 n, $45,49,67,73,75$.

${ }^{56}$ Tamże, s. 82; APBK Rkps I-d-30: Rozkład kazań w kościele oo. bernardynów w Krakowie. (1920-1930), s. 8, 10; Rkps I-a-4: Kronika..., s. 335.

${ }^{57}$ R. Gu s t a w OFM, Klasztor i kościót św. Józefa..., s. 192.

${ }^{58}$ APBK Rkps I-d-30: Rozkład kazań..., s. 5, 11, 23,33; Rkps I-a-4: Kronika..., s. 334. 
rafii i innych ośrodków pracy duszpasterskiej. Zapraszani byli przez duszpasterzy wielu parafii i ośrodków zarówno będących pod zarządem księży diecezjalnych, jak i tych, którymi opiekowało się duchowieństwo zakonne, szczególnie z Zakonu Braci Mniejszych. Większość z nich wspomagana była przez ojców doraźnie, ale były też takie, z którymi podjęto regularną współpracę. Takich stałych miejsc wyjazdowych było co najmniej trzy. Jedno z nich stanowiła wspólnota wiernych oraz pielgrzymi gromadzacy się wokół sanktuarium maryjnego w Kalwarii Zebrzydowskiej ${ }^{59}$. Swiatynia ta obsługiwana była przez bernardynów, dla których konwent ufundował w Kalwarii w I połowie XVII w. starosta generalny krakowski, a od 1601 r. wojewoda krakowski, Mikołaj Zebrzydowski ${ }^{60}$. Ze względu na pątniczy charakter miejsca kalwaryjscy bernardyni chętnie korzystali z pomocy w spełnianiu czynności duszpasterskich od swych współbraci zakonnych z Krakowa ${ }^{61}$. Nawiązując do tej tradycji również w interesującym nas okresie, w roku 1931 władze zakonne zdecydowały, by jak w przeszłości, zobowiazać konwent stradomski do stałego okolicznościowego posługiwania w wyżej wymienionym sanktuarium. Zarządzenie to dotyczyło okresu Odpustu Wielkotygodniowego i Wniebowzięcia NMP, kiedy to wierni najliczniej gromadzili się przed obrazem Najświętszej Panienki i na nabożeństwie drogi krzyżowej celebrowanym na pobliskich dróżkach kalwaryjskich $^{62}$. Obok Kalwarii Zebrzydowskiej, ważną placówką duszpasterską dla krakowskich bernardynów była w tym czasie parafia Poborowice koło Proszowic, należąca wówczas do diecezji kieleckiej. Miała ona dla nich o tyle wyjątkowe znaczenia, że od dnia 1 czerwca 1920 r. znajdowała się pod ich zarządem. Jej pierwszym administratorem mianowany został wikary konwentu, o. Paulin Wilczyński, który miał pełnić tę funkcję przez okres jednego roku. Był on jednak przynajmniej początkowo wspierany przez swych współbraci w pełnionych tam obowiązkach ${ }^{63}$.Konwent krakowski utrzymywał stały kontakt również ze wspólnotą wiernych w Mogilanach, miejscowości położonej na południe od Krakowa, na Pogórzu Wielickim. Tutejsza parafia erygowana została w 1440 r. przez cystersów szczyrzyckich i od końca lat osiemdziesiątych XIX wieku związana była $\mathrm{z}$ okolicznościowym duszpasterstwem bernardyńskim ${ }^{64}$.

${ }^{59}$ APBK Rkps I-a-4: Kronika..., s. 241; Rkps I-d-30: Rozkład kazań..., s. 1.

${ }^{60} \mathrm{M}$. Zebrzydowski był ponadto w latach 1596-1601 marszałkiem wielkim koronnym, a jeszcze wcześniej starostą stężyckim, lanckrońskim, bolesławskim i śniatyńskim. - W. D w o r z a c z e k, Genealogia. Tablice, Warszawa 1959, tabl. 134 (Zebrzydowscy h. Radwan).

${ }^{61} \mathrm{O}$ pierwszej takiej pomocy duszpasterskiej wiadomo już w roku 1600 , kiedy to krakowscy bernardyni brali udział w uroczystościach poświęcenia pierwszej kaplicy w Kalwarii, pod wezwaniem Podniesienia Krzyża św. - H. E. W y c z a w s k i OFM, Kalwaria Zebrzydowska. Historia klasztoru Bernardynów i kalwaryjskich dróżek, Kalwaria Zebrzydowska 1987, s. 58.

${ }^{62}$ APBK Rkps I-c-6: Księga kurend..., s. 141.

${ }^{63}$ APBK Rkps I-a-4: Kronika ..., s. 158n.

${ }^{64}$ M. Macis zew ski , Mogilany, [w:] Stownik Geograficzny Królestwa Polskiego $i$ innych krajów słowiańskich, pod red. F. Sulimierskiego, B. Chlebowskiego, W. Walewskiego, t. 6, Warszawa 1885, s. 579; APBK Rkps I-a-4: Kronika..., s. 157. 
Wyżej wymienione ośrodki pracy bernardynów na rzecz rozwoju wewnętrznego wiernych, gromadzących się w świątyniach krakowskich oraz zamiejscowych, w dużej mierze ilustrują całokształt ich wysiłków w zakresie duszpasterstwa zwyczajnego. Można na ich przykładzie wykazać różnorodność tej posługi, jak również okoliczności jej spełniania. W tym względzie należy zauważyć, że głównym zadaniem udających się tam ojców było głoszenia Słowa Bożego, celebrowanie Mszy św., bądź nabożeństw paraliturgicznych, w tym przede wszystkim nieszporów ${ }^{65}$. Nie były to jednak jedyne formy posługiwania w kościołach obcych. W niektórych przypadkach, bowiem istniała też potrzeba niesienia pomocy przy słuchaniu spowiedzi. Bernardyni chętnie korzystali z podobnych okazji, gdyż stwarzały im możliwość sprawowania kierownictwa duchowego poprzez konfesjonał także poza ich świątynią ${ }^{66}$.

Szeroko zakrojona działalność duszpasterska prowadzona przez bernardynów z krakowskiego konwentu w kościołach obcych, obejmowała także nauki rekolekcyjne parafialne i stanowe. Wśród rekolekcjonistów, którymi mógł pochwalić się konwent krakowski, odnaleźć można tych najbardziej znanych i cenionych jak o. Czesław Bogdalski, czy współpracujący z nim niekiedy bł. o. Anastazy Pankiewicz ${ }^{67}$. Podobnie jak w przypadku duszpasterstwa zwyczajnego zapraszano bernardynów z rekolekcjami zarówno do świątyń krakowskich, jak i tych znajdujących się na terenie innych miejscowości. Na obszarze własnego miasta głosili nauki wobec osób stanu świeckiego oraz zakonnego. Bywali w szpitalu bonifratrów, gdzie starali się wspomagać braci szpitalnych w doskonaleniu swych cnót ${ }^{68}$. W swej pracy rekolekcyjnej zetknęli się również z albertynkami. W klasztorze sióstr na Kazimierzu wspierali ojcowie rozwój duchowy aspirantek i nowicjuszek. Starali się także wpłynąć na kształtowanie życia wewnętrznego ubogich i bezrobotnych, o których los byli zawsze szczególnie zatroskani. Umożliwili im to albertyni, zapraszając ich w tym celu do swojej świątyni ${ }^{69}$.

W przypadku rekolekcji zamiejscowych prowadzonych przez naszych zakonników warto zwrócić uwage na ich zasięg terytorialny. Zdarzało się, bowiem że docierali do obszarów położonych w dość odległych zakatkach Polski. Za przykład mogą tu posłużyć dwa miasta - Łomża oraz Łódż ${ }^{70}$. Częściej jednak głosili oni nauki rekolekcyjne w miejscowościach znajdujących się w południowo - wschodnich częściach kraju. W samej archidiecezji krakowskiej nie mieli ku temu zbyt wielu okazji, choć można tu wspomnieć przynajmniej o Mogilanach. Natomiast szczególnie ulubionymi obszarami ich działalności rekolekcyjnej i duszpasterskiej w ogóle, była wówczas diecezja kielecka. W jej granicach znajdowało się co najmniej kilka miejscowości, do których bernardyni udawali się z posługą nauczania. Wśród nich były także,

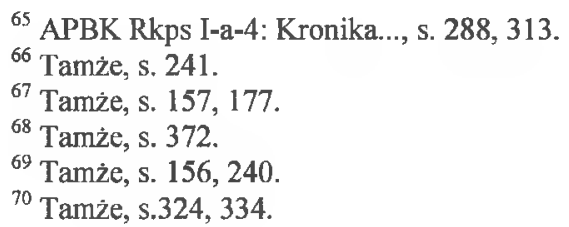


już wcześniej wspomniane Poborowice, choć zdecydowanie częściej zapraszano ich do parafii w Wawrzyńczycach ${ }^{71}$. Nie rzadko jednak zdarzało im się spełniać swe duszpasterskie obowiązki w miastach i wioskach także innych diecezji położnych w tej części kraju. Nie sposób wymieniać tutaj wszystkich miejscowości, gdyż liczba ich jest dość znaczna. Ograniczę się, zatem do podania choć kilku dla zobrazowania działalności ojców w tym zakresie. Spośród nich wskazać można na Zamość czy Rzeszów. Ponadto mieli oni także okazję nauczać w Zawichoście, Przeworsku, Janowie Lubelskim oraz Soka$\mathrm{lu}^{72}$. Dość szczególne znaczenie dla krakowskich bernardynów miały rekolekcje głoszone w lipcu 1923 r. w Lipnicy Murowanej koło Bochni, w diecezji tarnowskiej. Rekolektantami byli tu wspomniani już ojcowie - Czesław Bogdalski oraz bł. Anastazy Pankiewicz. Celem ich było przygotowanie tutejszych mieszkańców na uroczystość przeniesienia relikwii bł. Szymona do nowo wybudowanego kościoła pod jego wezwaniem, w jego rodzinnej miejscowości, jaką była właśnie Lipnica. Zadanie, którego podjęli się ojcowie miało dla nich w pewnym sensie osobisty charakter, gdyż ów Błogosławiony spoczywał i odbierał swój szczególny kult w świątyni, której byli gospodarzami i z której to miało dokonać się przeniesienie ${ }^{73}$.

Podsumowując należy dodać, że raczej sporadycznie zdarzało im się nauczać kilkakrotnie, czy nawet dwukrotnie w tej samej miejscowości. Z reguły, bowiem przynajmniej w przeciagu dwudziestolecia międzywojennego, czyniono to tylko raz. Nie można również wskazać na jakąś jedną konkretną okoliczność, która nadawałaby rekolekcjom bernardyńskim specyficzne znamię, choć trzeba przyznać, że najczęściej głoszone były w okresie Wielkiego Postu.

$\mathrm{Na}$ osobną uwagę zasługuje również działalność misyjna bernardynów z Krakowa. Bernardyni Prowincji Niepokalanego Poczęcia NMP, a więc w tym także i ci z krakowskiego konwentu, zawsze pojmowali range powierzonego Kościołowi zadania i jako jego członkowie zawsze byli gotowi wspierać go w trudach jego realizacji. Dla tego celu na kapitule prowincjalnej odbytej w Leżajsku w roku 1921 postanowiono powołać spośród współbraci grono misjonarzy ${ }^{74}$. Mieli oni zarówno prowadzić misje ludowe na terenia kraju, jak i w razie potrzeby udawać się w podróże zagraniczne dla zjednywania Chrystusowi nowych wyznawców wśród innowierców. Pozostali członkowie wspólnoty zakonnej, którzy nie zostali obdarzeni takim powołaniem mogli przyczynić się do rozwoju misji poprzez modlitwę i jałmużnę. Miało im w tym pomagać powołanie w roku 1924 Franciszkańskiego Związku Misyjnego z siędzibą we Lwowie ${ }^{75}$.

W czasach międzywojennych w klasztorze krakowskim mieszkało kilku misjonarzy, w tym nie tylko pracujący na terenie kraju, ale też i ci którzy znani

\footnotetext{
71 Tamże, s. $211,141$.

${ }^{72}$ Tamże, s. 325, 340; Rkps I-d-30: Rozkład kazań...,s. 26.

${ }^{73}$ APBK Rkps I-a-4: Kronika..., s. 284, 287.

${ }^{74}$ APBK Rkps I-c-6: Księga kurend..., s. 78.

${ }^{75}$ Zob. s. $12-13$.
} 
byli z głoszenia Ewangelii poza jego granicami. Nie wszyscy oni w czasie swego tutejszego pobytu pcłnili tę funkcje fâktycznie. Niektórych, bowiem władze prowincji skierowały tutaj dla nieco innych celów. Tak było w przypadku dwóch misjonarzy zagranicznych -0 . Paulina Wilczyńskiego ${ }^{76}$ oraz br. Zachariasza Banasia ${ }^{77}$, którzy w interesującym nas okresie dali się poznać jako misjonarze w Mandżurii i Japonii. Obaj, zanim podjęli trud nawracania, przebywali na Stradomiu, gdzie o. Wilczyński pełnił funkcje administratora parafii w Poborowicach, a br. Banaś, był ogrodnikiem. Swoich sił w misjach zagranicznych próbował także o. Piotr Wilk-Witosławski ${ }^{78}$. W roku 1930 wraz z wyżej wspomnianymi oraz nie związanym już z Krakowem, głośnym misjonarzem o. Gerardem Piotrowskim, udał się do nowo objętej przez prowincję placówki na Sachalinie japońskim. Praca ta nie okazała się jednak zgodna $\mathrm{z}$ jego powołaniem, toteż po upływie kilku miesięcy powrócił do kraju. Kiedy w roku 1933 o. Paulin został skierowany do klasztoru krakowskiego, w odróżnieniu od swych dwóch współtowarzyszy z misji, pełnił tutaj funkcję misjonarza krajowego ${ }^{79}$. Obok niego do pracy misyjnej wśród wiernych w Polsce zarząd prowincji wyznaczał w latach międzywojennych takie każdorazowego kustosza tutejszego konwentu. W latach dwudziestych był nim bł. Anastazy Jakub Pankiewicz, który spełniał tę funkcje do momentu przeniesienia go do klasztoru w Łodzi w roku 1932, a więc także za czasów przełożeństwa o. Floriana Rogowskiego. Po nim zaś obowiązki kustosza i misjonarza przejął o. Kalikst Stuligłowa. Ponadto posługę tego rodzaju mieli sprawować w czasie

${ }^{76}$ Paulin Franciszek Wilczyński OFM urodził się w dniu 8 stycznia 1881 r. w Bądziemyślu w diecezji tarnowskiej. Do zakonu wstapił w $1899 \mathrm{r}$. Śluby wieczyste złożył w roku 1903, a w trzy lata później przyjął święcenia kapłańskie. Studiował we Lwowie i Krakowie. W latach 1925-1929 był misjonarzem w Harbinie w Mandżurii, a od 1930 r. na Sachalinie japońskim. W roku 1940 wyjechał do Chin, a potem do USA - H. E. W y c z a w s k i OFM, Bernardyni polscy..., s. 406; K. G r u d z iń s k i OFM, Wilczyński Paulin Franciszek, [w:] Stownik Pisarzy Franciszkańskich..., s. 518 n.; B. M i g d ał OFM, Bernardyni poza granicami Polski i ich praca w Prowincji w latach 1914-1978, t. 4, Kalwaria Zebrzydowska 1978, t. 4, s. $181 \mathrm{n}$. (mps w posiadaniu APBK Sygn. 150).

77 Zachariasz Sebastian Banaś OFM - urodzony w Jelnej w diecezji przemyskiej 5 stycznia 1892 r. Do zakonu wstapil w roku 1912, a w 1923 złożył śluby wieczyste. W latach 1926-1929 był misjonarzem w Harbinie w Mandżurii, a os 1930-1940 na Sachalinie japońskim. Zmarł w roku 1955 - H. E. W y c z a w sk i OFM, Bernardyni polscy..., s. 405; K. G ru d z i ń s k i OFM, Banaś Zachariasz Sebastian, [w:] Stownik Pisarzy Franciszkańskich..., s. 35; B. M i g d a 1 OFM, Bernardyni poza granicami Polski..., t. 1, s. 3.

${ }^{78}$ Piotr Wilk-Witosławski żyl w latach 1902-1960. Do Zakonu Braci Mniejszych wstapił w roku 1918. Śluby wieczyste złożył w 1923 r., a trzy lata później przyjął święcenia kapłańskie. Był znany jako misjonarz i organizator tercjarstwa. W Krakowie przebywał w latach 1933-1936. W tym czasie pełnił funkcję dyrektora Trzeciego Zakonu przy tutejszym klasztorze oraz zdobył tytuł magistra teologii na Uniwersytecie Jagiellońskim - H. E. W y c z a w s k i OFM, Bernardyni polscy..., s. 406; W. F. Mu ra w i e c OFM, Wilk-Witostawski Piotr Feliks, [w:] Stownik Pisarzy Franciszkañskich..., s. 520 n.; B. M i g d a $\mathrm{OFM}$, Bernardyni poza granicami Polski..., s. 189 n.

${ }^{79} \mathrm{~K}$. Kaczor, Powstanie i rozwój polskiej placówki misyjnej ojców bernardynów na Sachalinie japonskim (Karafuto) w latach 1932-1948, Kraków-Katowice 1979, s. 21, 23 (praca magisterska w posiadaniu APBK sygn. 24); Schematismus (...) pro anno Domini 1933. Lwów 1932, s. 18. 
swego pobytu w tutejszym klasztorze $-o$. Wiktoryn Rudolf ${ }^{80}$ oraz jeden $\mathrm{z}$ najbardziej znanych tutejszych duszpasterzy o. Czesław Bogdalski ${ }^{81}$.

Działalność misyjna bernardynów ze Stradomia właściwie koncentrowała się w tamtym okresie na obszarze Polski i objęła swym zasiegiem trzy diecezje. W roku 1921 ojcowie Bogdalski i Pankiewicz głosili nauki misyjne w Poborowicach w diecezji kieleckiej. Natomiast w roku 1932 już sam bł. Anastazy Pankiewicz udał się w podobnym celu do diecezji podlaskiej ${ }^{82}$. Najczęściej jednak mieli ojcowie sposobność pracować na terenie archidiecezji lwowskiej. Jeszcze w roku 1926 o. Pankiewicz wraz z o. Rogowskim, który wówczas był jeszcze gwardianem klasztoru w Kole, mieli za zadanie przygotować wiernych w kościele lwowskim św. Andrzeja, poprzez misje, do uroczystości franciszkańskich związanych z obchodami 700-lecia śmierci św. Antoniego $\mathrm{z}$ Padwy ${ }^{83}$. W latach trzydziestych udawano się tam $\mathrm{z}$ misjami dwukrotnie, w tym w 1933 r. przy okazji uroczystości 200-lecia beatyfikacji Jana $\mathrm{z}$ Dukli ${ }^{84}$.

W przypadku zaś misji zagranicznych zasadniczo należy uznać, że zaangażowanie ojców w tym względzie ograniczało się do modlitwy oraz wsparcia finansowego za pośrednictwem Franciszkańskiego Związku Misyjnego. Wynika to mianowicie $\mathrm{z}$ faktu, że choć jak wyżej wspomniano, kilku ojców mieszkało przejściowo w Krakowie to jednak trzeba dodać, że zostali skierowani do swoich placówek $\mathrm{z}$ innych klasztorów, w których przebywali zanim przybyli do tutejszego konwentu lub, do których później zostali przeniesieni ${ }^{85}$. W czasie swej pracy i przebywania w krajach misyjnych, w sensie prawnym pozostawali nadal mieszkańcami tych klasztorów jako przydzielonych im na stałe i do nich powracali w czasie urlopów.

Rekolekcje oraz misje ludowe w większości przypadków służyły bernardynom z Krakowa również do propagowania franciszkańskiego ideału życia wśród świeckich. Tercjarstwo, ogromnie zaniedbane w czasach niewoli narodowej, zyskało swego gorącego propagatora głównie w osobie o. Czesława Bogdalskiego. Jego zaangażowanie w tym względzie sięga wprawdzie końca wieku XIX, niemniej jednak przedmiotem naszego zainteresowania będzie przede wszystkim okres II Rzeczypospolitej. W tym czasie zrodziła się tradycja odbywania ogólnopolskich kongresów tercjarskich. Początek jej dał wła-

${ }^{80}$ Wiktoryn Franciszek Rudolf OFM - urodził się we wsi Głogowie w diecezji przemyskiej, w dniu 24 stycznia 1890 r. Do zakonu wstapił w roku 1906. Profesje wieczysta złożył w roku 1911, a w 1914 r. przyjął święcenia kapłańskie. Był misjonarzem i kapelanem wojskowym. Zginał w Dachau w dniu 9 kwietnia 1942 r. - E. S e r o n a , Ojciec Wiktoryn Rudolf, [w:] Cudem ocaleni, Londyn 1978, s. 247, 251; B. M i g d ał OFM, Bernardyni poza granicami Polski..., t. 3, s. 95.

${ }^{81}$ Schematismus (...) pro anno Domini 1927. Lwów1927, s. 19; Schematismus (...) pro anno Domini 1933. Lwów1932, s. 18; Schematismus (...) pro anno Domini 1939. Radecznica 1939, s. 23.

${ }^{82}$ APBK Rkps I-a-4: Kronika..., s. 160, 335.

${ }^{83}$ Tamże, s. 305.

${ }^{84}$ Tamże, s 348, 365.

${ }^{85}$ B. M i g d a 1 OFM, Bernardyni poza granicami Polski..., t. 4, s. 182, 190. 
śnie o. Bogdalski inicjując zwołanie pierwszego takiego kongresu do Krakowa w roku 1921, z okazji 700-lecia założenia Trzeciego Zakonu przez św. Franciszka z Asyżu ${ }^{86}$. Jubileusz ten stał się dla niego doskonałą okazją zarówno do rozwinięcia na szeroką skalę akcji propagandowej, jak i do ustalenia stanu faktycznego sieci tercjarskiej w kraju ${ }^{87}$. Również większość kongregacji założonych kanonicznie $w$ dwudziestoleciu międzywojennym w ramach duszpasterstwa prowadzonego przez krakowski konwent bernardyński, zawdzięczała jemu swoje powstanie. Tylko w nielicznych przypadkach był on wspomagany lub wyręczany przez bł. o. Anastazego Pankiewicza, który koncentrował się w swej działalności na rzecz tercjarstwa raczej na wizytowaniu i nauczaniu. W latach trzydziestych dwudziestego stulecia, kiedy o. Bogdalski podupadał na zdrowiu i zmarł w 1935 r., godnie zastapił go w tych czynnościach o. Piotr Wilk-Witosławski. On to po śmierci o. Bogdalskiego stał się głównym duszpasterzem Trzeciego Zakonu, mimo iż był nie kontynuatorem akcji propagandowej ${ }^{88}$. Praca ich obu obejmowała swym zasięgiem przede wszystkim obszar południowej i południowo-wschodniej Polski. Szczególnie duże zaangażowanie wykazali na południowym obszarze metropolii warszawskiej - głównie w diecezji sandomierskiej. Pracowali także na terenie metropolii lwowskiej i tutaj wskazać można szczególnie diecezję przemyską ${ }^{89}$. Oczywiście na szeroką skalę działali również w diecezjach metropolii krakowskiej. Najczęściej w samej diecezji krakowskiej oraz w diecezjach: kieleckiej, tarnowskiej oraz nieco rzadziej śląskiej. Natomiast raczej sporadyczne zdarzało im się pracować w diecezji częstochowskiej ${ }^{90}$.

Omawiając problem zaangażowania o. Bogdalskiego w sprawę krzewienia idei tercjarstwa wśród wiernych trzeba też podkreślić, że tak on jak i jego współpracownicy i następcy poczynili stosowne wysiłki, aby dzieło pomnożenia liczby kongregacji tercjarskich okazało się trwałe w skutkach. Wszyscy oni, bowiem zdawali sobie sprawę $\mathrm{z}$ tego, że nie wystarczy tylko dokonać aktu erekcji gminy, by zakorzenić Trzeci Zakon w tradycjach duszpasterskich parafii. Należało w dalszym ciagu czuwać nad jej rozwojem duchowym. $Z$ tego powodu starali się oni w miarę możliwości regularnie głosić dla tych wspólnot nauki rekolekcyjne, szczególnie wielkopostne, oraz dokonywać częstych wizytacji kanonicznych ${ }^{91}$.

Dzieje krakowskiego klasztoru od samego początku jego istnienia związane są z życiem wielu zasłużonych dla Kościoła zakonników. Wśród nich są i tacy, którzy za swą świątobliwość i poświęcenie w służbie bliźniemu wyniesieni zostali na ołtarze i wskazani nam jako wzór do naśladowania. Ich praca

${ }^{86}$ Zob. s. 10 .

${ }^{87} \mathrm{Na}$ podstawie kwestionariuszy o. Bogdalski ustalił że obok tercjarzy świeckich istnieja jeszcze w Polsce tercjarze zakonni i kongregacyjni, kierujący się zasadami życia wspólnotowego - APBK Rkps RGP-k-82: Teki ..., t. 65, s. 88, 91 .

${ }^{88}$ APBK Rkps I-a-4: Kronika..., s. 263, 362; Rkps I-d-30: Rozkład kazań...,s. 34.

${ }^{89}$ APBK Rkps I-a-4: Kronika..., s. 263.

${ }^{90}$ Kronika, „Dzwonek Trzeciego Zakonu” R. 40:1926, nr 8, s.503; APBK Rkps I-a-4: Kronika..., s. 310, 313, 363.

${ }^{91}$ APBK Rkps I-d-30: Rozkład kazań..., s. 234. 
społeczna przysporzyła konwentowi dobrego imienia zarówno w środowisku ludzi bogatych i światłych, jak i wśród warstw uboższych.

Lata dwudzieste i trzydzieste wieku XX były czasem wytężonej pracy na rzecz odrodzenia życia zakonnego i religijnego w Polsce po okresie zastoju wywołanego prześladowaniami ze strony zaborców. Bernardyni ze Stradomia w pełni docenili i wykorzystali możliwość swobodnego głoszenia Dobrej Nowiny. Bazując na doświadczeniach wieków poprzednich z zapałem rozwinęli różnorakie formy kierownictwa duchowego. W tym zakresie poświęcali czas nie tylko wiernym gromadzącym się przy ich świątyniach, ale często udawali się w odległe zakątki kraju, by tam spełniać swe oḅowiązi. Obok celebracji Mszy świętych i licznych nabożeństw paraliturgicznych, głoszenia Słowa Bożego oraz słuchania spowiedzi świętej, dużą uwagę przywiązywali do nauczania poprzez rekolekcje. Zazwyczaj miały one charakter rekolekcji ludowych, $\mathrm{z}$ reguły głoszonych przy okazji Wielkiego Postu, ale zdarzało im się też prowadzić nauki stanowe. W kilku przypadkach mieli też możność odprawiania misji ludowych. Niektórzy z ojców mogli także pochwalić się doświadczeniem w pracy poza granicami kraju, choć niestety nie $\mathrm{z}$ okresu pobytu w Krakowie. Tutejszy klasztor, bowiem nie był w tym czasie bezpośrednio zaangażowany w misje zagraniczne. Specyficzną dla ich duszpasterstwa i wymagającą dużego zaangażowania była także posługa spełniana w ramach prowadzenia i propagowania wśród wiernych Trzeciego Zakonu Franciszkańskiego. Ich wysiłki w tym zakresie pozwoliły na jego odrodzenie, dały podwaliny nowej jego organizacji oraz przyczyniły się do wypracowania zwyczaju odbywania zjazdów tercjarskich o zasięgu regionalnym i krajowym. Podobną wage przywiązali także do pasterzowania $w$ ramach bractw kościelnych, prowadzonych przez nich przy własnej świątyni. W interesującym nas okresie było ich kilka, ale najprężniej działało Arcybractwo Niepokalanego Poczęcia NMP. Podobnie jak wszystkie inne miało ono na celu rozwijanie życia religijnego swoich członków. Ważną formą sprawowania duszpasterstwa przy kościele św. Bernardyna było także krzewienie kultu Chrystusa Pana i Jego Matki oraz błogosławionych i świętych, w szczególności franciszkańskich. Obok tych zadan, podejmowanych przede wszystkim $\mathrm{z}$ myślą o świeckich wiernych Kościoła, sprawowali oni również stałą opiekę duchową nad bernardynkami z krakowskiego klasztoru św. Józefa.

Rozmach i gorliwość z jaką bernardyni wykonywali swą posługe w omawianym okresie przy własnej światyni i w innych ośrodkach, jest tym bardziej godna uwagi, że podejmowana była w czasach wyjątkowo trudnych i wymagających wielu wyrzeczeń. Nie ze względu na trudności prawne, bo odrodzona Rzeczpospolita pod tym względem raczej sprzyjała rozwojowi życia kościelnego i religijnego, ale $\mathrm{z}$ powodu trudnej sytuacji materialnej będącej konsekwencją lat niewoli i wojny oraz kryzysu gospodarczego przełomu lat dwudziestych i trzydziestych. 